\title{
FILSAFAT ISLAM: KEJAYAAN DAN KONFLIK DENGAN ORTODOKSI
}

\author{
Ruslan Ibrahim \\ Institut Agama Islam (IAI) Muhammadiyah Bima \\ ruslanamarizqi@gmail.com
}

\begin{abstract}
Abstrak
Dinamika sejarah filsafat Islam pernah mengalami kejayaan sekaligus menghadapi masalah pertentangan yang membuatnya tidak bisa berkembang secara pesat disebabkan penolakan dari kaum ortodoksi Islam. Era Ibnu Sina merupakan era kejayaan filsafat Islam dimana gagasan dan konsep pemikiran filosofisnya menjadi rujukan masyarakat pada zamannya. Berbeda dengan Sang Hujjatul Islam, Imam al-Ghazali. Berdasarkan proses pencarian yang dilakukannya, ia menemukan bahwa kebenaran atau Islam yang orisinal itu ada pada konsep dan pemikiran yang ortodoks (murni). Konsep sang pembela Islam tidak berjalan mulus, karena Ibnu Rusyd yang merupakan salah satu tokoh penting dunia Muslim yang sering melontarkan kritikannya terhadap pemikiran Islam ortodoksi yang diwakili oleh Imam al-Ghazali. Bahkan al-Ghazali sering dituduh sebagai penyebab kejumudan dalam dunia Islam.
\end{abstract}

Kata Kunci: Filsafat Islam, kejayaan, ortodoksi Islam.

\section{Pendahuluan}

akikat dari filsafat Islam adalah akal dan al-Qur'an. Filsafat Islam tidak mungkin

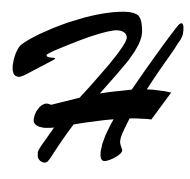
tanpa akal dan al-Qur'an. Akal yang memungkinkan aktivitas itu menjadi aktivitas filsafat dan al-Qur'an menjadi ciri ke-Islamannya. Tidak dapat ditinggalkannya al-Qur'an dalam Filsafat Islam adalah lebih bersifat spiritual sehingga al-Qur'an tidak membatasai akal tetap bekerja dengan otonom penuh. ${ }^{1}$ Dengan perkembangan pemikiran manusia, maka upaya untuk menjadikan Islam sebagai sifat filsafat terus dikembangkan oleh para pemikir muslim. Filsafat Islam adalah filsafat yang bercorak Islami. Dalam hal ini Islam mendapat posisi sebagai sifat maupun corak dari filsafat. Filsafat islam bukan filsafat tentang Islam. Filsafat Islam artinya berpikir yang bebas, radikal, dan berada pada taraf makna, yang mempunyai sifat, corak dan karakter yang menyelamatkan dan memberikan kedamaian hati. Dengan demikian, filsafat Islam memiliki keberpihakan yang lebih bernilai humanis yaitu pada keselamatan dan kedamaian. ${ }^{2}$

\footnotetext{
${ }^{1}$ Musa Asy'ari dalam Irman Fatimah (editor), Filsafat Islam: Kajian Ontologis, Epistemologi, Aksiologi Historis Prospektif. (Yogjakarta: LESFI, 1992), 15. Baca juga Aris Try Andreas Putra, "Pemikiran Filosofis Pendidikan Ibnu Sina dan Implikasinya Pada Pendidikan Islam Kontemporer", dalam Literasi, Volume VI, No. 2 Desember 2015, 192. Seseorang yang mengkaji Islam dari sumbernya al-Qur'an dan alHadits dengan kesadaran yang mendalam akan mengeluarkan hasil pikiran yang universal mengenai sesuatu hal, baik filsafat wujud, pengetahuan, dan filsafat nilai.

${ }^{2}$ Musa Asy'arie, Filsafat Islam Sunnah Nabi dalam Berpikir, (Yogyakarta: LESFI, 2001), 6. Bandingkan dengan Ira M. Lapidus, Sejarah Sosial Umat Islam (Jakarta: Rajawali Pers, 2004), 323, dan John L. Esposito, Ensiklopedi Oxford Dunia Islam Modern, (Bandung: Mizan, 2001), 71-72.
} 
Berdasarkan analisis tersebut, dalam tulisan ini penulis akan menguraikan tentang kejayaan kerajaan filsafat Islam dan konflik dengan Ortodoksi. Yang menjadi persoalannya adalah kapan filsafat Islam mengalami masa kejayaan, dan dalam hal apa saja filsafat Islam mengalami konflik dengan ortodoksi?. Uraian berikut ini terkait dengan kejayaan filsafat Islam dan konfliknya dengan ortodoks.

\section{Tinjauan Historis Kejayaan Filsafat Islam}

Diskursus kejayaan filasafat Islam, yang menarik untuk ditelaah yakni masa perekmbangan filsafat Islam pada masa Ibnu Sina, Dia-lah filosof muslim yang paling banyak menulis buku-buku ilmiah sampai soal-soal yang berkenaan dengan cabang dan ranting filsafat Islam. Sedangkan, para filosof yang datang sesudahnya tidak mencapai kemajuan yang berarti, malah sebagian diantara mereka hanya menguraikan buku-buku yang ditulis Ibnu Sina, seperti: Al-Razi dan Al-Thusi. Pada zamannya, filsafat Islam mencerminkan kepribadian Ibnu Sina sehingga ia menjadi sasaran serangan kalangan yang mengencam filsafatnya dan menghendaki kehancurannya. ${ }^{3}$

Dalam usaha untuk menemukan hakekat kebenaran, ia mempunyai pandangan yang mandiri, dengan kata lain bahwa ia tidak mengikuti paham-paham atau aliran lain dalam menemukan kebenaran, baik dalam bidang filsafat maupun dalam bidang keagamaan. Baginya cukup mengangkat satu dalil pokok diantara dalil yang membicarakan tentang eksistensi Tuhan, yang pada saat itu banyak diperbincangkan orang. Ia menyerukan teori pemikiran baru, yaitu Tuhan adalah wajib al-wujud (Allah pasti ada). Ia menyerukan teori eksistensi itu setelah mengadakan pembagian rasional mengenai soal "ada" (maujudeksistensi) menjadai pasti (wujud), mungkin, dan mustahil. Maka karena itu, Ibnu Sina dapat di pandang sebagai perwujudan filsafat Islam, setelah banyak dasar filsafat tersebut yang diletakkannya. Ia berpendapat bahwa seluruh alam wujud ini mempunyai asal-usul atau ada kaitan dengan wujib al-wujud.

Ibnu Sina, dalam teorinya mengatakan bahwa Tuhan mengetahui segala sesuatu. Dialah sebab utama dari segala sesuatu itu, karenanya Dia mengetahui seluruh sebab akibat semua kejadian. Dengan demikian, Tuhan mengetahui sejak zaman azali misalnya, suatu gerhana matahari akan terjadi dengan seluruh karakteristiknya, dan pada suatu titik tertentu dalam proses sebab akibat gerhana tersebut. Teori lain yang dikemukakan Ibnu Sina adalah tentang kebangkitan. Ibnu Sina berpendapat bahwa semua roh manusia akan terus hidup, sedangkan raga tidak akan bisa dibangkitkan lagi. ${ }^{4}$

Ketika al-Ghazali hendak melancarkan "serangan intelektual" dan kencaman terhadap filsafat dan kaum filosof, ia tidak menemukan filosof lain kecuali Ibnu Sina. Untuk menyanggah Ibnu Sina, al-Ghazali menulis sebuah buku yang berjudul "Tahafut al-

\footnotetext{
${ }^{3}$ Ahmad Fuad Al-Ahwani, Filsafat Islam (Jakarta: Pustaka Firdaus, 1997), 82.

${ }^{4}$ Fazlur Rahman, Islam, (Bandung: Pustaka, 2000), 169.
} 
Falasifah", 5 yang membahas penyimpangan-penyimpangan para filosof, bahkan ia menuduh para filosof sebagai pembuat Bid'ah. ${ }^{6}$ Ibnu Sina adalah seorang ahli pikir dalam sejarah Islam. Ia menghasilkan sintesi filsafat paling luas dan tegas, tersatu, yang mencakup tata maupun menulis dalam Bahasa Arab. Ia berusaha menciptakan suatu filsafat muslim yang mengintegrasikan dalil agama dalam sistemnya. ${ }^{7}$ Kejayaan filsafat Islam pada masa Ibnu Sina merupakan suatu yang sangat berharga bagi masyarakat. Hal ini, dapat dilihat dari beberapa teorinya tentang eksistensi Tuhan dan hukum kausalitas, yang sampai sekarang ummat Islam banyak yang mengikuti konsepnya. Selain itu, beberapa karya ilmiahnya dapat dijadikan sebagai sumber acuan, seperti kitabnya mengenai Al-Qanun fi Al Thib, Al-Syifa, Al-Nafat yang merupakan ringkasan $\mathrm{Al}$-Syifa ${ }^{8}$ dan lain-lain. Al-Syifa' yang berisi filsafat dan terdiri atas empat bagian, yaitu: logika, fisika, matematika, dan metafisika. ${ }^{9}$ Manfaatnya bukan saja dirasakan oleh ummat Islam pada zaman kejayaan filsafat Islam (masanya), akan tetapi tersebar dan dijadikan acuan bagi masyarakat non-muslim. Bahkan sampai sekarang, perkembangan ilmu kedokteran dapat dirasakan oleh masyarakat diseluruh dunia.

\section{Konflik Filsafat Islam dengan Ortodoksi}

Ortodoksi merujuk paa dua nilai, yaitu, bagi orang-orang beriman bahwa ortodoksi merupakan ekspresi otentik dari Agama sebagaimana yang diajarkan oleh salaf al-shaleh; literaturnya menggambarkan kelompok-kelompok yang menentang sebagai sekte-sekte. Sedangkan bagi ahli sejarah, ortodoksi merujuk pada penggunaan ideologis Agama oleh kelompok-kelompok yang bersaing dalam wilayah politis yang sama; seperti, sunni mendukung kekhalifahan dan menyebutkan dirinya (ahl-al-sunnah wa al-jama'ah). ${ }^{10}$ Dalam tradisi pemikiran Islam, ortodoks tidak mengenal yang namanya tradisi kritik epistemologis ${ }^{11}$, segalanya dianggap sudah mapan. Ibnu Rusyd (1126-1198) pernah

\footnotetext{
${ }^{5}$ Terkait dengan isi kitab al-Ghazali Tahafut Al-Falasifah, akan diuraikan pada bagian berikutnya mengenai konflik filsafat Islam dengan ortodoksi.

${ }^{6}$ Al-Ahwani, Filsafat Islam, . 88-89. Filsafat dalam perspektif agama dianggap sebagai bid ah sehingga keberadaan pemikiran filsafat bisa mengusik kemapanan agama. Selengkapnya dapat dibaca pada Muhamad Nur, "Pendekatan Filosofis Dalam Studi Islam" dalam Jurnal Didaktika Islamika Volume 5 Nomor 1 Pebruari $2015,27$.

${ }^{7}$ JWM Bakker SY, Sejarah Filsafat Islam, (Yogyakarta: Kanisius, 1978), 51.

45.

${ }^{8}$ Untuk lebih jelasnya mengenai karya ilmiah Ibnu Sina, dapat dilihat dalam Bakker, Sejarah Filsafat,

${ }^{9}$ Kitab ini terdiri dari 18 jilid. Baca uraian Abuddin Nata, Ilmu Kalam Filsafat Dan Tasawuf, (Jakarta: Raja Grafindo Persada, 1995), 93.

10 Mohammad Arkoun, Islam Kontemporer Menuju Dialog Antar Agama, (Yogyakarta: Pustaka Pelajar, 2001), 17.

${ }^{11}$ Sudarsono, Ilmu Filsafat Suatu Pengantar, (Jakarta: Rineka Cipta, 1993), 137. "epistemologi” di dalam bahasa Inggris dikenal dengan istilah "theory of knowledge". Epistemologi berasal dari asal kata "episteme" dan "logos". Episteme berarti pengetahuan, dan logos berarti teori. Dalam rumusan yang lebih rinci epistemologi adalah salah satu cabang filsafat yang mengkaji secara mendalam dan radikal tentang asal mula pengetahuan, struktur, metode, dan validitas pengetahuan. Baca juga Muhammad In'am Esha, Menuju Pemikiran Filsafat, (Malang: UIN Malang Press, 2010), 98. Epistemologi menyangkut beberapa hal penting
} 
melontarkan kritikannya terhadap tokoh ortodoks yaitu al-Ghazali (1058-1111), namun kritikannya tersebut ibarat "menepuk air didulang" dilingkungan pemikiran sunni-ortodoks, hingga nampaknya kritikan Ibnu Rusyd dianggap tidak berlaku oleh muslim ortodoks. Yang terjadi adalah kemendegaan tradisi kritik epistemologi, yakni dari kritik yang dinamiskontruktif berubah menjadi pembakuan ajaran ortodoksi yang immипиe dari nuansa pemikiran kritis. ${ }^{12}$ Ekses dari pembakuan ajaran ortodoks bukan saja kemendegaan berpikir bagi ummat Islam, tapi disisi lain, model kritik Ibnu Rusyd digunakan oleh pemikir nonmuslim, dan buktinya adalah sampai sekarang non-muslim (barat) lebih maju dibandingkan dengan ummat Islam. ${ }^{13}$

Al-Ghazali merupakan salah satu tokoh yang banyak dibicarakan oleh berbagai kalangan sebagai muslim ortodoks yang melakukan penolakan terhadap filsafat. Pada mulanya ia sempat mempelajari filsafat secara otodidak tanpa bantuan orang lain sebagai guru atau pembimbing. Dalam kegiatan belajar tersebut, al-Ghazali menemukan beberapa penyimpangan filsafat dalam menyingkapkan kebenaran. Melihat penyimpangan para filosof, kemudian dalam "Tahafut al-Fasalifah", al-Ghazali menyalahkan pendapat ahli filsafat dalam masalah ke-Tuhan-an. ${ }^{14}$ Serangan al-Ghazali terhadap filsafat Islam ketika itu menimbulkan pengaruh yang sangat besar terhadap perkembangan filsafat dan pengetahuan didunia Islam Timur. Seolah-olah serangan al-Ghazali merupakan suatu bombardier yang menyebabkan munculnya kebencian terhadap filosof muslim. Kebencian tidak terbatas pada pendapat para ahli filsafat dalam masalah ketuhanan tetapi pada semua yang berbau filsafat dan ilmu-ilmu yang berasal dari tokoh-tokoh filsafat itu merupakan suatu yang harus dijauhi.

Dengan penolakan al-Ghazali terhadap filsafat, membuat orang yang tidak sepaham dengannya memunculkan dugaan bahwa al-Ghazali adalah penyebab terlambatnya perkembangan filsafat dan Ilmu penegtahuan didunia Islam dalam waktu yang relatif lama.

yaitu epistemologi berkenaan dengan sifat pengetahuan, kemungkinan, cakupan, dan dasar-dasar pengetahuan, epistemologi membahas tentang reliabilitas pengetahuan dan epistemologi melakukan investigasi tentang sumber, struktur, metode, dan validitas pengetahuan.

${ }^{12}$ M. Amin Abdullah, Falsafah Kalam di Era Post Modernisme, (Yogyakarta: Pustaka Pelajar, 1995), 58.

${ }^{13}$ Samsul Nizar, Sejarah Pendidikan Islam: Menelusuri Sejarah Pendidikan Era Rasulullah Sampai Indonesia, Cet. I, (Jakarta: Kencana, 2007), 88. Ada beberapa hal yang menjadi penyebab melemahnya kekuatan Islam yang secara otomatis mempengaruhi kemunduran, antara lain: Pertama, filsafat Islam (bercorak sufistik) yang berlebihan masuk ke alam islami di Timur. Di samping itu, juga berlebihannya filsafat yang bercorak rasionalistis ke dunia Islam di Barat. Kedua, umat Islam terutama pada pemerintahnya (khlalifah, sultan, amir-amir) melalaikan ilmu pengetahuan dan kebudayaan, dan tidak memberi kesempatan untuk berkembang. Ketiga, terjadinya pemberontakan-pemberontakan yang dibarengi dengan serangan dari luar, sehingga menimbulkan kehancurankehancuran yang mengakibatkan berhentinya kegiatan pengembangan ilmu pengetahuan dan kebudayaan di dunia Islam.

${ }^{14}$ Mohammad Kosim, "Ilmu Pengetahuan Dalam Islam (Perspektif Filosofis-Historis)", dalam Tadrîs, Volume 3. Nomor 2, 2008, 135. Ia menulis Tahäfut al-Falāsifah sebenarnya bertujuan untuk menghidupkan kembali kajian keagamaan yang, menurutnya, telah terjadi banyak penyimpangan akibat ulah sebagian filosof khususnya Ibnu Sina yang berdampak pada semakin menjamurnya semangat pemikiran bebas yang membuat orang meninggalkan ibadah. 
Dalam hal ini, tidak semua tokoh setelahnya sepaham dengan pemikirannya, seperti Ibnu Rusyd yang tampil menyerang al-Ghazali dan membela para tokoh filosof muslim. AlAhwani mengencam al-Ghazali bahwa dirinya telah membunuh dunianya sendiri, dan sebaiknya al-Ghazali dilahirkan didunia luar Islam. ${ }^{15}$ Dipihak lain, al-Ghazali dianggap sebagai ulama besar, beliau mendapat gelar Hujjatul Islam yang menyelamatkan ummat Islam dari bahaya yang hendak menghancurkan terutama yang menyangkut masalah akidah dan akhlak. ${ }^{16}$ Imam al-Ghazali menghasilkan berbagai karya-karya besar dalam berbagai ilmu-ilmu Islam, yang berarti menghidupkan kembali ruh keagamaan ditengah ummat Islam yang sedang mengalami kemerosotan akibat pengaruh asing.

Terlepas dari al-Ghazali dianggap sebagai Hujjatul Islam, secara tidak sadar ia telah mewariskan tradisi "anti kritis" terhadap pengikutnya dalam melihat dan mengamati segala fenomena yang ada. Sebenarnya beliau sangat kritis terhadap persoalan yang ada, seperti kritikannya terhadap konsep metafisika Ibnu Sina. Tetapi kenyataan ummat Islam diwariskan dengan warisan popular Ihya' Ulumuddin yang memuat mengenai mempertahankan ajaranajaran ortodoks dengan doktrin yang membuat pengikutnya kurang tepat menafsirkan, sehingga membuat ummat Islam lemah dalam mengkritisi segala persoalan.

Dalam menentang konsep metafisika Ibnu Sina, ia dibantu dan dilindungi oleh Nidham Al-Mulk, Perdana Mentri Sulthan Alparslan dari Bani Saljuq (yang dibunuh oleh orang-orang Syi'ah Isma'iliyyat, mengajar di Universitas Nidhamiyah Baghdad, dan mengokohkan paham sunni khususnya mazhab Syafi'i dalam fiqh dan Asy'ari dalam kalam ${ }^{17}$ sehingga sekarang dapat dilihat banyak ummat Islam yang "monoton" pada salah satu aliran dan mazhab. Persoalan berikutnya ialah "Pantaskah al-Ghazali dianggap sebagai penghambat perkembangan filsafat dan ilmu pengetahuan di dunia Islam, sementara disisi lain al-Ghazali dianggap sebagai "Hujjatul Islam"?.

Untuk menyeimbangkan persoalan yang muncul, disini penulis akan menguraikan bidang-bidang yang termasuk dalam klasifikasi dari filsafat menurut al-Ghazali. Dalam klasifikasinya, bahwa yang termasuk dalam bidang filsafat, antara lain: matematika, manthiq, fisika, metafisika, ilmu politik, dan filsafat moral. Sebagian dari bidang klasifikasi filsafat tersebut, menurut al-Ghazali fardhu kifayah hukumnya untuk dipelajari. Bila demikian

\footnotetext{
${ }^{15}$ Muhammad Aziz Siregar, Islam Untuk Berbagai Aspek Kehidupan, (Yogyakarta: Tiara Wacana, 1999), 47.

${ }^{16}$ Kebesaran al-Ghazali sebagai 'Hujjat al-Islam' ternyata telah begitu mengungkung kesadaran masyarakat muslim, sehingga tanpa mengkaji kembali persoalan tersebut dengan teliti, mereka telah ikut menyatakan perang dan antipati terhadap filsafat. Baca A. Khudori Soleh, "Mencermati Sejarah Perkembangan Filsafat Islam" dalam Jurnal Tsaqafah, Vol. 10, No. 1, Mei 2014, 77. Sampai sekarang di perguruan tinggi sekalipun, jika ada kajian filsafat umumnya masih lebih banyak dilihat pada sisi sejarah dan metafisikanya, bukan aspek epsitemologi, metodologi, atau sistem penalarannya. Baca juga Amin Abdullah, "Teologi dan Filsafat dalam Perspektif Globalisasi llmu dan Budaya” dalam Mukti Ali dkk, Agama dalam Pergumulan Masyarakat Kontemporer, (Yogyakarta: Tiara Wacana, 1998), 265.

${ }^{17}$ Nurchalish Madjid, Islam Doktrin dan Peradaban, (Jakarta: Paramadina, 1992), 172.
} 
adanya, maka al-Ghazali tidak menolak atas konsep filsafat secara keseluruhan, akan tetapi bahwa Al-Ghazali hanya menolak konsep filosof tentang metafisika.

Konsep para filosof tentang metafisika yang di serang al-Ghazali ialah: pertama, penyangkalan para filosof akan kebangkitan badan pada hari kiamat. Dengan demikian yang mendapat siksa hanya ruh saja. Terkait dengan ini, Ibnu Sina berpandangan bahwa semua roh manusia akan terus hidup, sedangkan raga (badan) tidak akan dibangkitkan lagi. ${ }^{18}$ Lebih jauh dikatakan bahwa secara garis besar kebangkitan raga adalah suatu mythos imaginative yang diilhamkan kedalam pikiran Nabi dengan tujuan untuk mempengaruhi akhlak dan moral orang awam. ${ }^{19}$

Kedua, keterbatasan pengetahuan Tuhan tentang hal universal saja, sedangkan untuk khusus diluar jangkauan Tuhan. Dalam rangka teori Aristoteles dan Plotinus, Tuhan hanya mengetahui hal-hal yang universal saja. Sedangkan Ibnu Sina mengatakan bahwa Tuhan mengetahuui segala sesuatu, Dia-lah sebab awal (utama) dari segala sesuatu, karenanya dia mengetahui seluruh sebab akibat kejadian. ${ }^{20}$ Ketiga, pendirian para filosof akan kekekalan alam. Para filosof muslim mengemukakan bahwa alam adalah efek pribadi Tuhan, yang denganya ia mempunyai hubungan unilateral dalam ketergantungan absolut, dalam menyusun doktrin ini, filosof mencari bantuan Neoplatinos monistik tentang emanasi ${ }^{21}$ dan menolak paham Aristoteles tentang dualism, antara Tuhan dan materi. Karena itu, materi tidak dianggap mempunyai indepeden dan sebaliknya berasal dari Yhun dan berakhir dengan emanasi. ${ }^{22}$ Semua proposisi-proposisi semacam ini tidak diterima oleh al-Ghazali. Sedangkan Fazlur Rahman mengemukakan bahwa dasar yang paling krusial dari ketidakpuasaan ortodoksi terhadap pendangan keagamaan para filosof adalah terkait dengan sifat agama itu sendiri. Teori filsafat tentang Wahyu kenabian yang melihat dalam diri Nabi adanya suatu roh dan kecerdasan yang tinggi, yang mampu berhubungan dengan kecerdasan universal atau Malaikat tertinggi, tidaklah ditolak. Sifat wahyu, yang secara esensial dinyatakan intelektual oleh filosof, dan terutama bahwa agama hanyalah sebagai bentuk

${ }^{18}$ Manusia ini tidak dihidupkan lagi badannya, maka rohnya yang abadi itu akan mengalami siksa dan kesenangan. Lihat Ahmad Hanafi, Pengantar Filsafat Islam, (Jakarta: Bulan Bintang, 1990), 9.

${ }^{19}$ Rahman, Islam, 169-170.

${ }^{20}$ Ibid.

${ }^{21}$ Realitas emanasi dianalogkan dengan arti kata-kata sambung dan preposisi, seperti "lahir dari...", bergantung pada...", "diterangi oleh...", dan lain sebagainnya, semua kata yang digunakan dalam definisi emanasi hanya berarti, seperti yang dapat dilihat, tinadakan murni, dan imanen oleh pelaku sebagai menifestasi kebenaran substansi, karena realitas emanasi tidak punya arti yang jelas dan bias didefinisikan dalam diri sendiri terpisah dari prinsip subtansinya. Mahmud Nasir Ilmu Al-Hudhuri (Telaah Filsafat Ilmu atas Pemikiran Mehdi Hairi Yazri), (Dinamika" Jurnal Kajian Kritis Pendidikan Islam Vol. 2 No 1, 2016), 19. Baca juga Mehdi HairiYazdi, The Principles of Epistemologi in Islamic Philosophy Knowledge by Presence (New York: State University of New York, 1992), 125. Kebenaran esensial emanasi sepenuhnya terletak dalam kebenaran sumber subtansinya.

${ }^{22}$ Rahman, Islam, 168. Penjelasan terkait dapat dilihat dalam Syafi'I Ma'arif, Peta Bumi Intelektualisme Islam di Indonesia (Bandung: Mizan, 1995), 58-59. Fazlur Rahman, Islam dan Modernitas, (Bandung: Pustaka, 1995), 39-40. Rahman, Islam, 172-3. 
simbolis dari kebenaran intelektual, ditolaknya. Sifat realita hakiki bagi Islam ortodoks tak dapat diintelektualisasi begitu saja, tetapi harus diilhami dengan aktivitas moral. Tetapi warisan terpenting filosof yang dapat diterima oleh ortodoksi adalah pembagian Wujud menjadi Wajib Al-Wujud dan Mukmin Al-Wujud, yang memberikan manfaat besar bagi pembuktian kalam tentang eksistensi Tuhan, Alam semesta sebagai sesuatu yang tergantung memerlukan Wajib Al-Wujud sebagai penyebabnya. ${ }^{23}$

Berdasarkan uraian tersebut, sangat sulit untuk menuduh Al-Ghazali sebagai tokoh anti-intelektual, sebab bukan semua masalah yang berkaitan dengan filsafat ditolaknya, akan tetapi persoalan yang metafisis menjadi sasarannya, bukan justru ia mewajibkan ummat Islam untuk belajar filsafat. Orang lupa bahwa ketika al-Ghazali menyerang konsep metafisika Ibnu Sina, sebenarnya tidak serta merta memfonis semua bidang filsafat. Logika, ilmu-ilmu alam tidak diserang. Memahami kritikan al-Ghazali terhadap Ibnu Sina tanpa terkecuali sesungguhnya tidak pada tempatnya. Terlebih lagi memfonis salah_untuk tidak mengatakan ingkar padanya. ${ }^{24}$ Maka, untuk itu kita sebaiknya memperbanyak membaca karya-karya populernya, seperti: Ihya' Ulumuddin, Tahafut Al-Falasifah, dan lain-lain. Dengan memahami karya populernya, setidaknya kita akan dapat memahami sampai dimana konsep filsafat dan para filosof yang mendapatkan serangan dari al-Ghazali.

Konflik filsafat Islam dengan ortodoksi, yang harus kita pahami bahwa al-Ghazali adalah manusia biasa yang tidak luput dari kelemahan-kelemahan, dan begitu juga para filosof. Namun, yang perlu untuk dikritisi dari proses dialetika filsafat Islam Vs Ortodoksi adalah berefek pada saling mengklaim keunggulan masing-masing pihak. Kelompok ortodoksi menganggap bahwa pemikiran para filosof adalah bid'ah dan kafir. Sedangkan pada pihak filosof menganggap al-Ghazali sebagai pembuat kemujudan. Oleh karena itu, ada perbedaan pendapat para filosof dengan kelompok ortodoks merupakan suatu yang lazim. Sekarang, kita harus siap menerima kenyataan perbedaan dalam berpendapat, untuk terusmenerus mencari kebenaran.

\section{Penutup}

Bertolak dari uraian sebelumnya, maka dalam hal ini dapat dijelaskan bahwa filsafat Islam mengalami masa kejayaan pada masa Ibnu Sina (989-1063). Ini terbukti dengan beberapa buku-buku ilmiah yang ditulisnya termasuk persoalan cabang filsafat Islam sebagaimana yang diuraikan sebelumnya. Selain itu kejayaan filsafat Islam pada masa Ibnu Sina dapat dilihat dengan pikiran-pikiran filosof yang menonjol dan paling lengkap, serta pada waktu itu orang banyak yang mengkaji masalah filsafat, bahkan hampir semua bidang filsafat pada waktu itu dibicarakan. Konsep Ibnu Sina tentang Tuhan, yang menurutnya

\footnotetext{
${ }^{23}$ Fazlur Rahman, Cita-Cita Islam (Yogyakarta: Pustaka Pelajar, 2000), 180-191.

${ }^{24}$ M. Amin Abdullah, Studi Agama: Normativitas atau Historisitas (Yogyakarta: Pustaka Pelajar, 1999), 231.
} 
Tuhan adalah Wajib Al- Wujud (pasti), mungkin dan mustahil merupakan bukti lain, karena teori ini menjadi konsep masyarakat pada masanya.

Terkait dengan konflik filsafat Islam dengan ortodoksi, dalam hal ini yang perlu untuk diperhatikan konsep Ibnu Sina masalah metafisika. Konsep metafisika Ibnu Sina merupakan konsep yang dianggap oleh para ortodoks terutama Imam al-Ghazali sebagai konsep yang akan membawa umat Islam kepada kekafiran. al-Ghazali sebagai manusia biasa yang memiliki kelemahan, bisa saja kita mengkritis-nya, akan tetapi bukan pada tempatnya untuk menuduh al-Ghazali sebagai penghambat perkembangan pemikiran dan ilmu pengetahuan didunia Islam, apalagi dengan mengatakannya kafir. Untuk memahami pikiran-pikiran Imam al-Ghazali hendaknya terlebih dahulu membaca dan memahami isi karya-karya populernya. Sebab, beberapa kalangan juga menilai al-Ghazali sebagai pembela Islam.

\section{Daftar Pustaka}

Abdullah, M. Amin. Falsafah Kalam di Era Post Modernisme. Yogyakarta: Pustaka Pelajar, 1995.

Studi Agama: Normativitas atau Historisitas. Yogyakarta: Pustaka Pelajar, 1999.

. Teologi dan Filsafat dalam Perspektif Globalisasi llmu dan Budaya" dalam Mukti Ali dkk, Agama dalam Pergumulan Masyarakat Kontemporer. Yogyakarta: Tiara Wacana, 1998.

Al-Ahwani, Ahmad Fuad. Filsafat Islam. Jakarta: Pustaka Firdaus, 1997.

Arkoun, Mohammad. Islam Kontemporer Menuju Dialog Antar Agama. Yogyakarta: Pustaka Pelajar, 2001.

Asy'arie, Musa. Filsafat Islam Sunnah Nabi dalam Berpikir. Yogyakarta: LESFI, 2001.

Bakker SY, JWM. Sejarah Filsafat Islam. Yogyakarta: Kanisius, 1978.

Fatimah, Irma. Filsafat Islam: Kajian Ontologis, Epistemologi, Aksiologi Historis Prospektif. Yogjakarta: LESFI, 1992.

Fazlur Rahman. Cita-Cita Islam. Yogyakarta: Pustaka Pelajar, 2000. Islam dan Modernitas. Bandung: Pustaka, 1995.

............... Islam. Bandung: Pustaka, 2000.

Hanafi, Ahmad. Pengantar Filsafat Islam. Jakarta: Bulan Bintang, 1990.

In'am Esha, Muhammad. Menuju Pemikiran Filsafat. Malang: UIN Malang Press, 2010.

Kosim, Mohammad. Ilmu Pengetahuan Dalam Islam (Perspektif Filosofis-Historis)", dalam Tadrîs, Volume 3. Nomor 2, 2008.

L. Esposito, John. Ensiklopedi Oxford Dunia Islam Modern. Bandung: Mizan, 2001.

M. Lapidus, Ira. Sejarah Sosial Umat Islam. Jakarta: Rajawali Pers, 2004.

Ma'arif, Syafi'i. Peta Bumi Intelektualisme Islam di Indonesia. Bandung: Mizan, 1995. Madjid, Nurchalish. Islam Doktrin dan Peradaban. Jakarta: Paramadina, 1992. 
Nasir, Mahmud, Ilmu Al-Hudhuri (Telaah Filsafat Ilmu atas Pemikiran Mehdi Hairi Yazri), dalam Dinamika: Jurnal Kajian Kritis Pendidikan Islam Vol. 2 No 1, 2016.

Nata, Abuddin. Ilmu Kalam Filsafat Dan Tasawuf. Jakarta: Raja Grafindo Persada, 1995.

Nizar, Samsul. Sejarah Pendidikan Islam: Menelusuri Sejarah Pendidikan Era Rasulullah Sampai Indonesia, Cet. I,. Jakarta: Kencana, 2007.

Nur, Muhamad. Pendekatan Filosofis Dalam Studi Islam" dalam Jurnal Didaktika Islamika Volume 5 Nomor 1 Pebruari 2015.

Putra, Aris Try Andreas. "Pemikiran Filosofis Pendidikan Ibnu Sina dan Implikasinya Pada Pendidikan Islam Kontemporer”, dalam Literasi, Volume VI, No. 2 Desember 2015.

Siregar, Muhammad Aziz. Islam Untuk Berbagai Aspek Kehidupan. Yogyakarta: Tiara Wacana, 1999.

Soleh, A. Khudori. Mencermati Sejarah Perkembangan Filsafat Islam" dalam Jurnal Tsaqafah. Vol. 10, No. 1, Mei 2014.

Sudarsono. Ilmu Filsafat Suatu Pengantar. Jakarta: Rineka Cipta, 1993.

Yazdi, Mehdi Hairi. The Principles of Epistemologi in Islamic Philosophy Knowledge by Presence. New York: State University of New York, 1992. 